declined during $1^{\text {st }} / 2^{\text {nd }}$ pregnancy trimester (SLEDAI-2K:1.91 $\left.\pm 2.09,1.70 \pm 2.22\right)$ ) but increased during the $1^{\text {st }}$ and $2^{\text {nd }}$ trimester post labor (SLEDAI-2K: $2.47 \pm 4.29$ and $2.52 \pm 3.2$ ).

Conclusion: This is the first Greek inception cohort with prospective monitoring of pregnant SLE patients. Adverse outcomes occur with prematurity being the most frequent. In our cohort disease activity tends to increase during $1^{\text {st }}$ and $2^{\text {nd }}$ trimester post-labor without serious relapses. Vigilant monitoring during pregnancy and post-labour is advised.

References:

[1] Bundhun PK, Soogund MZ, Huang F. Impact of systemic lupus erythematosus on maternal and fetal outcomes following pregnancy: A meta-analysis of studies published between years 2001-2016. J Autoimmun 2017;79:17-27. [https://doi. org/10.1016/j.jaut.2017.02.009] [PMID: 28256367]

[2] Wei S, Lai K, Yang Z, Zeng K. Systemic lupus erythematosus and risk of preterm birth: a systematic review and meta-analysis of observational studies. Lupus 2017;26:563-71. [https://doi. org/10.1177/0961203316686704] [PMID: 28121241]

Acknowledgments: Hellenic Rheumatology Association

Disclosure of Interests: Stella Ntali: None declared, Lina Pantazi: None declared, Kyriaki Boki: None declared, Dionysis Nikolopoulos: None declared, Antonis Fanouriakis: None declared, Despoina Dimopoulou: None declared, loannis Kallitsakis Grant/research support from: MSD, Speakers bureau: Genesis pharma, Bristol-Myers Squibb, CHARALAMPOS PAPAGORAS: None declared, Vasiliki Dania: None declared, Evgenia Emmanouilidou: None declared, George Bertsias Grant/research support from: GSK, Consultant of: Novartis

DOI: 10.1136/annrheumdis-2020-eular.6195

\section{FRI0544 THE EFFECT OF PATERNAL EXPOSURE TO IMMUNOSUPPRESSIVE DRUGS ON SEXUAL FUNCTION, REPRODUCTIVE HORMONES, FERTILITY, PREGNANCY AND OFFSPRING OUTCOMES: A SYSTEMATIC REVIEW}

L. F. Perez ${ }^{1}$, R. Dolhain ${ }^{1}$, S. Vorstenbosch ${ }^{2}$, W. Bramer ${ }^{3}$, E. Van Puijenbroek ${ }^{2,4}$, J. Hazes ${ }^{1}$, B. Te Winkel' ${ }^{2}{ }^{1}$ Erasmus MC, University Medical Center, Rheumatology, Rotterdam, Netherlands; ${ }^{2}$ Netherlands Pharmacovigilance Centre Lareb, 's-Hertogenbosch, Netherlands; ${ }^{3}$ Erasmus MC. University Medical Center, Medical Library, Rotterdam, Netherlands; ${ }^{4}$ University of Groningen, Groningen Research Institute of Pharmacy, PharmacoTherapy, Epidemiology and Economics, Groningen, Netherlands

Background: Information regarding the possible influence of immunosuppressive drugs on male sexual function and reproductive outcomes is scarce. Men diagnosed with immune-mediated diseases and a wish to become a father represent an important neglected population since they lack vital information to make balanced decisions about their treatment.

Objectives: To systematically review the literature for the influence of paternal immunosuppressive drug use on many aspects of male sexual health, such as sexual function, fertility, pregnancy outcomes and on their offspring health outcome.

Methods: A systematic literature search was performed in the bibliographic databases: Embase (via Elsevier embase.com), MEDLINE ALL via Ovid, Cochrane Central Register of Trials (via Wiley) and Web of Science Core Collection. Additionally, Google Scholar and the Clinical trial registries of Europe and the USA were searched. The databases were searched from inception until August 31th 2019. The searches combined keywords regarding male sexual function and fertility, pregnancy outcomes and offspring's health with a list of immunosuppressive drugs. Studies were included if they were published in English and if they included original data on male human exposure to immunosuppressive drugs.

Results: A total of 5867 references were identified among which we identified 163 articles fulfilling the eligibility criteria. Forty nine articles included pregnancy and offspring outcomes and 116 articles included sexual health outcomes. With the exception of large Scandinavian cohorts, most of the identified articles included a small number of participants. While a clear negative effect on sperm quality was evident for sulfasalazine and cyclophosphamide a dubious effect was identified for colchicine, methotrexate and sirolimus. In 3 articles exposure to TNF-a inhibitors in patients diagnosed with ankylosing spondylitis resulted in improved sperm quality. The information regarding pregnancy and offspring outcomes was scant but no large negative effect associated with paternal immunosuppressive drug exposure was reported.

Conclusion: Evidence regarding the safety of immunosuppressive drugs in men with a wish to become a father is inconclusive. The lack of standardization on how to evaluate and report male sexual function, fertility and reproduction as study outcomes in men exposed to immunosuppressive drugs is an important contributor to this result. Future research on this topic is needed and should be preferably done using standardized methods.

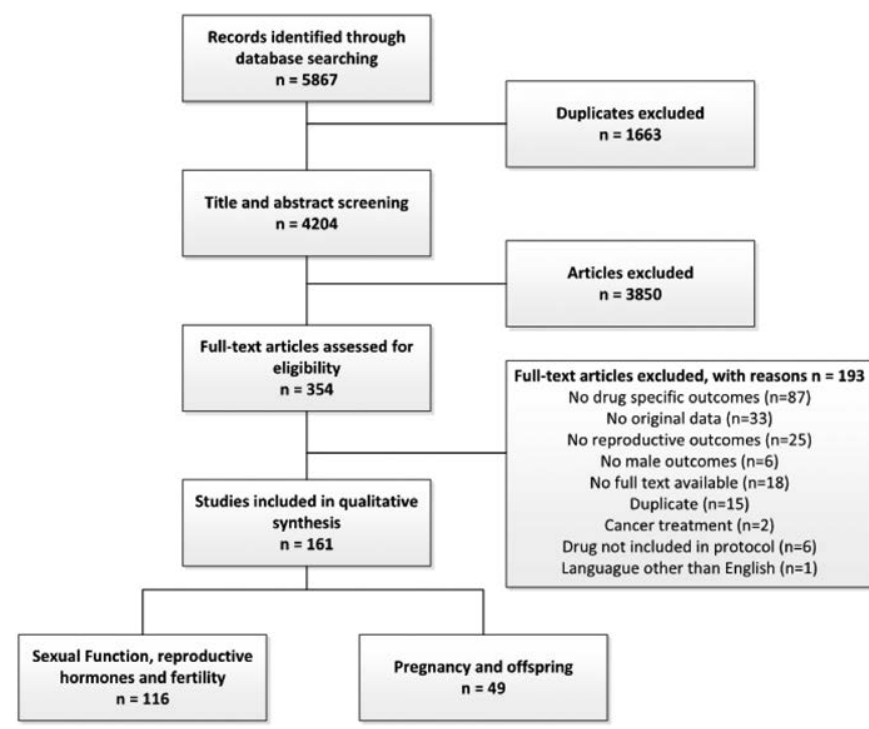

Figure 1. Flow diagram for study selection.

Disclosure of Interests: Luis Fernando Perez: None declared, Radboud Dolhain Grant/research support from: unrestricted grant from UCB Pharma, Saskia Vorstenbosch: None declared, Wichor Bramer: None declared, Eugène van Puijenbroek: None declared, Johanna Hazes: None declared, Bernke te Winkel: None declared

DOI: 10.1136/annrheumdis-2020-eular.3092

\section{FRI0545 1 A META-ANALYSIS OF GIANT CELL ARTERITIS TEMPORALLY AND ACROSS REGIONS}

D. Semenov ${ }^{1}, \mathrm{~K}_{\text {. LI }}{ }^{1}, \mathrm{M}$. Turk ${ }^{1}$, J. Pope ${ }^{1}$ on behalf of Schulich School of Medicine \& Dentistry. ${ }^{1}$ Schulich School of Medicine \& Dentistry, London, Canada

Background: Giant cell arteritis (GCA) is an immune-mediated disease of the large vessels, and occurs in adults over 50 years old ${ }^{1}$. It is the most commonly seen form of chronic vasculitis and is associated with significant rates of morbidity $^{2}$. This meta-analysis examines the geographical and temporal epidemiology of GCA, including incidence, prevalence and mortality.

\section{Objectives:}

1.To identify changes in incidence rate, prevalence, and mortality rate over time 2.To compare these rates between geographic regions around the world Methods: A systematic review of the English literature was conducted using the EMBase, Scopus and PubMed databases. Articles were included if they were cohort or cross-sectional studies with 50 or more patients with GCA and reported on population, location and time-frame parameters. Articles on mortality were included if they compared mortality to age and gender matched population. Review articles, case-control studies and case series were excluded. Two reviewers extracted data and a third verified inclusion of studies. Study quality was assessed by using the Strengthening the Reporting of Observational Studies in Epidemiology (STROBE) checklist. Mortality rate was standardized across cohorts to deaths per 1000 people per year.

Results: Of the 3569 citations identified by the literature search, 107 were included in analysis. The pooled incidence of GCA internationally was $10.00[9.22,10.78$ cases per 100000 people over 50 years old (Figure). This incidence was highest in Scandinavia 21.57 [18.90, 24.23], followed by North and South America 10.89 [8.78, 13.00], Europe 7.26 [6.05, 8.47], and Oceania 7.85 [1.48,17.19]. Nine studies reported prevalence. Pooled prevalence from these 9 was $51.74[42.04,61.43]$ cases per 100000 people over 50 years old. Overall, pooled mortality was 20.44 $[17.84,23.03]$ deaths/1000 per year. Mortality had a generally decreasing trend over the years of publication.

Conclusion: The incidence of GCA varies regionally almost 3-fold. Likely genetic and environmental factors may explain this trend. Incidence and prevalence are important for tracking the efficacy and side effects of current therapies, as well as planning for the costs of biologic treatment. 

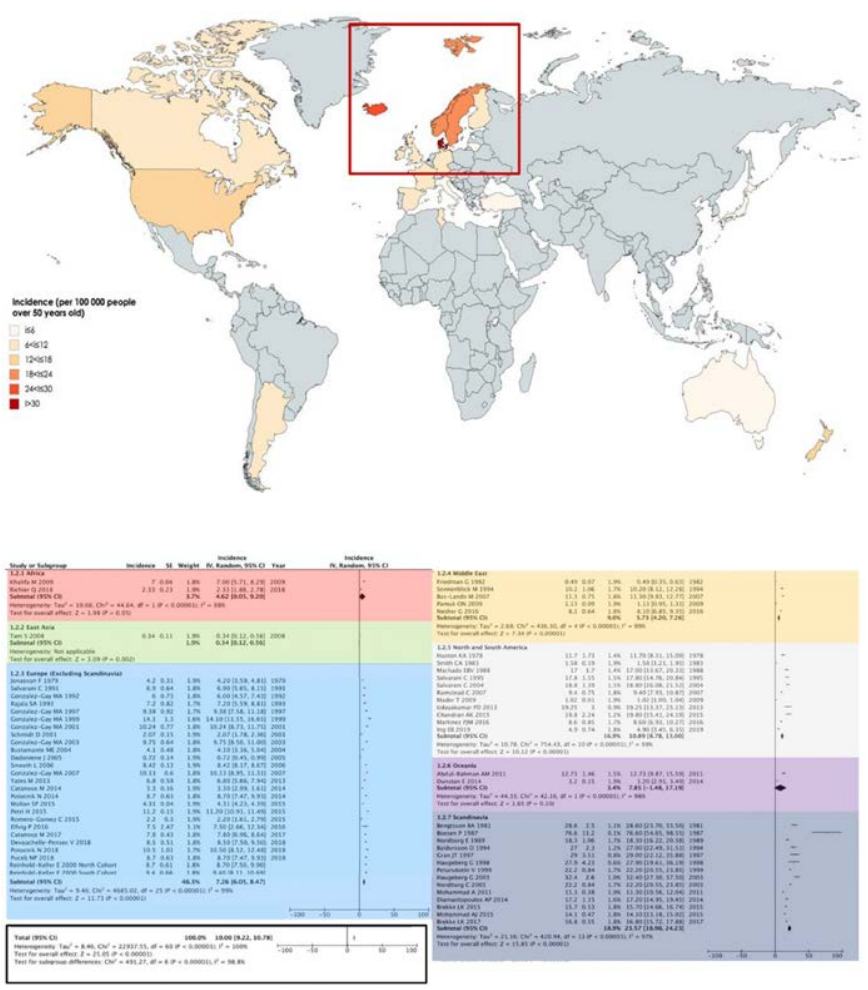

References:

[1] Floris A, Piga M, Cauli A, Salvarani C, Mathieu A. Polymyalgia rheumatica: an autoinflammatory disorder?. RMD Open. 2018;4(1):e000694. Published 2018 Jun 4. doi:10.1136/rmdopen-2018-000694

[2] Crow RW, Katz BJ, Warner JE, et al. Giant cell arteritis and mortality. J Gerontol A Biol Sci Med Sci. 2009;64(3):365-369. doi:10.1093/gero na/gln030

Acknowledgments: Both Daniel Semenov and Katherine Li equally contributed and sharing first authorship

Funding in part was from the Canadian Rheumatology Association summer studentship

Disclosure of Interests: Daniel Semenov: None declared, Katherine Li: None declared, Matthew Turk: None declared, Janet Pope Grant/research support from: AbbVie, Bristol-Myers Squibb, Eli Lilly \& Company, Merck, Roche, Seattle Genetics, UCB, Consultant of: AbbVie, Actelion, Amgen, Bayer, Boehringer Ingelheim, Bristol-Myers Squibb, Eicos Sciences, Eli Lilly \& Company, Emerald, Gilead Sciences, Inc., Janssen, Merck, Novartis, Pfizer, Roche, Sandoz, Sanofi, UCB, Speakers bureau: UCB

DOI: 10.1136/annrheumdis-2020-eular.3412

\section{FRI0546 GENDER DIFFERENCES OF RHEUMATIC DISEASES IN MEXICAN POPULATION: DATA FROM THE MEXICAN BIOLOGICS REGISTRY}

V. Rivera Teran ${ }^{1}$, D. Alpizar-Rodriguez ${ }^{1}$, S. Sicsik ${ }^{2}$, F. Irazoque-Palazuelos ${ }^{2}$, D. Miranda ${ }^{2}$, D. Vega-Morales², J. C. Casasola ${ }^{2}$, S. Carriloº ${ }^{2}$, A. Castillo², S. Duran Barragan², O. Muñoz ${ }^{2}$, A. Paz ${ }^{2}$, A. Peña ${ }^{2}$, A. Torres ${ }^{2}$, D. X. Xibille Friedmann ${ }^{2}$, A. Ramos ${ }^{2}$, J. F. Moctezuma ${ }^{2}$, F. Aceves ${ }^{2}$, E. Torres ${ }^{2}$, N. Santana ${ }^{2}$, M. Vazquez ${ }^{2}$, E. Zamora ${ }^{2}$, F. Guerrero², C. Zepeda ${ }^{2}$, M. Rivera ${ }^{2}$, K. Alvarado ${ }^{2}$, C. F. Pacheco Tena ${ }^{2}{ }^{1}$ Colegio Mexicano de Reumatología, Unidad de Investigación, Mexico City, Mexico; ${ }^{2}$ Colegio Mexicano de Reumatología, Mexico City, Mexico

Background: Most autoimmune diseases are more prevalent in women. Symptom severity, disease progression, response to therapy and overall survival differ between males and females with rheumatic diseases.

Objectives: To identify the characteristics of autoimmune diseases presentation and treatment between male and female population using information from the Mexican Adverse Events Registry (BIOBADAMEX).

Methods: BIOBADAMEX is a Mexican ongoing cohort that collects the information of patients using biologic and biosimilar drugs since 2016. For this study we included all patients enrolled in the registry and compared baseline clinical and disease characteristics, treatment and presence of adverse events between genders. We used logistic regression to analyze univariable associations.
Table 1. Baseline characteristics in the cohort by sex

\begin{tabular}{|c|c|c|c|}
\hline & $\begin{array}{c}\text { Women } \\
n=532(82 \%)\end{array}$ & $\begin{array}{c}\text { Men } \\
n=123(18 \%)\end{array}$ & $\begin{array}{c}\text { Univariable }^{a} \\
\text { OR(95\%Cl) }\end{array}$ \\
\hline Age, median (IQR) & $53(44-60)$ & $47(34-55)$ & $1.02(1.0-1.1)^{\star}$ \\
\hline Body Mass Index, median (IQR) & $27(23-31)$ & $26(23-30)$ & $1.0(0.9-1.1)$ \\
\hline Smoking, $\mathrm{n}(\%)$ & $28(5)$ & $18(16)$ & $0.3(0.2-0.6)^{\star}$ \\
\hline Disease duration, median (IQR) & $9(4-16)$ & $7(2-13)$ & $1.0(1.0-1.1)^{\star}$ \\
\hline \multicolumn{4}{|l|}{ Diagnosis, $n(\%)$ : } \\
\hline RA & $414(78)$ & $37(30)$ & $2.4(1.0-5.7)^{\star}$ \\
\hline AlJ & $12(2)$ & $5(4)$ & $0.5(0.1-1.9)$ \\
\hline AS & $37(7)$ & $56(46)$ & $0.1(0.1-0.4)^{\star}$ \\
\hline PsA & $19(4)$ & $15(12)$ & $0.3(0.1-0.8)^{\star}$ \\
\hline SLE & $17(3)$ & $3(2)$ & $1.2(0.3-5.2)$ \\
\hline Others & $33(6)$ & $7(6)$ & 1 \\
\hline \multicolumn{4}{|c|}{ Disease Activity indexes, median (IQR) } \\
\hline DAS28 ${ }^{\mathrm{a}}$ & $4.9(3.6-5.9)$ & $4.9(3.0-5.9)$ & $1.1(0.9-1.3)$ \\
\hline BASDAI $^{b}$ & $4.8(2.9-8)$ & $5.3(2.8-7.5)$ & $0.9(0.8-1.1)$ \\
\hline ASDAS $^{\mathrm{C}}$ & $3.2(1.9-4.5)$ & $3.9(2.5-4.7)$ & $0.8(0.6-1.2)$ \\
\hline SLEDAI $^{\mathrm{d}}$ & $14.5(5.0-19.5)$ & $25(25.0-31.0)$ & $0.6(0.4-1.1)$ \\
\hline High blood pressure, $\mathrm{n}(\%)$ & $77(15)$ & $14(12)$ & $1.3(0.7-2.4)$ \\
\hline Diabetes mellitus, $\mathrm{n}(\%)$ & $46(9)$ & $7(6)$ & $1.5(0.7-3.5)$ \\
\hline High cholesterol, $n(\%)$ & $41(8)$ & $8(7)$ & $1.2(0.4-2.6)$ \\
\hline Other comorbidities, $n(\%)$ : & $173(33)$ & $26(21)$ & $1.8(1.1-2.8)^{*}$ \\
\hline Use of previous biologic, $n(\%)$ : & $216(40)$ & $44(36)$ & $1.2(0.8-1.8)$ \\
\hline Use of steroids, $n(\%)$ : & 215 (42) & $34(29)$ & $1.7(1.1-2.7)^{\star}$ \\
\hline Use of DMARD, $n(\%)$ : & $418(79)$ & $89(72)$ & $1.4(0.9-2.2)$ \\
\hline Adverse events ${ }^{\mathrm{b}}, \mathrm{n}(\%)$ : & $69(13)$ & $14(11)$ & $1.2(0.7-2.1)$ \\
\hline Severe ${ }^{b}, \mathrm{n}(\%)$ : & $12(17)$ & $3(21)$ & $0.8(0.2-3.1)$ \\
\hline
\end{tabular}

Univariable logistic regression analysis. ${ }^{*} p<0.05 .{ }^{a} n=469,{ }^{b} n=99,{ }^{c} n=71,{ }^{d} n=19$,

Results: A total of 655 participants were analysed, of which $82 \%$ were female (Table 1). We found women were older with a median of 53 years compared to 46 years in men (OR 1.02, $\mathrm{Cl} 1.0-1.1)$. Smoking was higher in men (16\%) compared to women (5\%), (OR 0.3, $\mathrm{Cl} 0.2-0.6)$. Women had longer disease duration, 9 years compared to 7 years in men (OR 1, $\mathrm{Cl} 1.0-1.1)$. Rheumatoid arthritis (RA) was more prevalent in women (OR 2.7, $\mathrm{Cl}$ 1-6.9), while ankylosing spondylitis (AS) and psoriatic arthritis (PsA) were more prevalent in men (OR 0.2, $\mathrm{Cl} 0.1-0.4$, and OR 0.3, C 0.1-0.9 respectively). Women had more comorbidities than men (OR 1.8, $\mathrm{Cl} 1.1-2.8$ ) and used steroids more frequently (OR 1.7, $\mathrm{Cl} 1.1-2.7)$. Differences in disease activity were not found, however we noticed high activity scores among participants.

Conclusion: In our study we found sex differences regarding age and disease duration, being higher in women. As expected, the prevalence of RA was higher in women and $\mathrm{AS}$ and PSA in men. Overall, women used more steroids than men. An interesting finding was that patients had high disease activity. Future longitudinal analyses will allow us to analyse sex differences in disease progression and treatment response. References:

[1] Ortona E et al. Ann Ist Super Sanita 2016;52(2):205-12

[2] Ngo ST et al. Front Neuroendocrinol 2014;3(3):347-69

Disclosure of Interests: Vijaya Rivera Teran: None declared, Deshire Alpizar-Rodriguez: None declared, Sandra Sicsik: None declared, Fedra Irazoque-Palazuelos Consultant of: Bristol-Myers Squibb, Janssen, Pfizer Inc, Roche and UCB, Dafhne Miranda: None declared, David Vega-Morales: None declared, Julio Cesar Casasola: None declared, Sandra Carrilo: None declared, angel castillo: None declared, Sergio Duran Barragan: None declared, Omar Muñoz: None declared, Aleni Paz: None declared, Angélica Peña: None declared, Alfonso Tor res: None declared, Daniel Xavier Xibille Friedmann Consultant of: Lilly, Abbvie Speakers bureau: Lilly, Abbvie, Azucena Ramos: None declared, José Francisco Moctezuma: None declared, Francisco Aceves: None declared, Estefania Tor res: None declared, Natalia Santana: None declared, Miguel Vazquez: None declared, Erick Zamora: None declared, Francisco Guerrero: None declared Claudia Zepeda: None declared, Melanea Rivera: None declared, Kitzia Alvarado: None declared, Cesar Francisco Pacheco Tena: None declared DOI: 10.1136/annrheumdis-2020-eular.6091

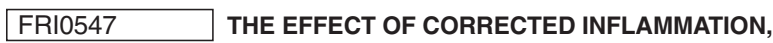 OXIDATIVE STRESS AND ENDOTHELIAL DYSFUNCTION ON FMD LEVELS IN PATIENTS WITH SELECTED CHRONIC DISEASES: A QUASI- EXPERIMENTAL STUDY}

M. Yilmaz ${ }^{1}$, M. Romano ${ }^{2}$, M. K. Basarali ${ }^{3}$, A. Elzagallaai ${ }^{4}$, M. Karaman ${ }^{1}$, Z. Demir ${ }^{1}$, M. F. Demir ${ }^{1}$, M. Seyrek ${ }^{5}$, F. Akcay ${ }^{1}$, N. Haksever ${ }^{6}$, D. Piskin ${ }^{4}$, R. Cimaz ${ }^{2}$, M. Rieder ${ }^{4}$, E. Demirkaya ${ }^{4} .{ }^{1}$ Epigenetic Health Solutions, Ankara, Turkey; ${ }^{2}$ Istituto Ortopedico Gaetano Pini, Milano, Italy; ${ }^{3}$ Ankara Provincial Health Directorate, Ankara, Turkey; ${ }^{4}$ Western University, London, Canada; ${ }^{5}$ Medisante Health Clinic, Ankara, Turkey; ${ }^{6}$ Yeditepe University, Istanbul, Turkey

Background: While the pathophysiology of chronic disorders varies there are three basic mechanisms - inflammation, oxidative stress and endothelial dysfunction - that are common in many chronic diseases. These mechanisms, 